\title{
The Impact of Oil Price Shocks on the Economic Growth and Development of Cross River State, Nigeria
}

\author{
Amenawo Ikpa Offiong ${ }^{1}$, Ignatius Ahmed Atsu ${ }^{1}$, Edward Ajaude ${ }^{1} \&$ Bassey Ina Ibor ${ }^{1}$ \\ ${ }^{1}$ Department of Banking and Finance, Faculty of Management Sciences, University of Calabar, Calabar, Nigeria \\ Correspondence: Bassey Ina Ibor, Department of Banking and Finance, Faculty of Management Sciences, University \\ of Calabar, Calabar, Nigeria. Tel: 234-817-718-3895.
}

Received: May 21, 2016

Accepted: June 14, 2016

Online Published: July 4, 2016

doi:10.5430/ijfr.v7n4p96

URL: http://dx.doi.org/10.5430/ijfr.v7n4p96

\begin{abstract}
With decreasing demand for fossil oil globally, international oil prices have fallen continuously, reaching an all time low of below $\$ 30$ lately. This has several implications on the Nigerian public finance structure at national and sub-national levels. The study investigated the impact of this plunge on the economic development of Cross River State, Nigeria and found that international oil price shocks affected the State's economy inversely, while a positive but insignificant relationship existed between the other model variables and the economic growth of the State. Consequently, the study recommends that CRS government should de-emphasize the over-reliance on crude oil revenue and seek and optimize earnings from other non-oil sectors of the economy.Further, the State's economy should be diversified to boost internally generated revenue with less dependence on Federal government revenue allocation. Finally, there should be effective machinery for checks and balances put up by the government to stem fiscal abuse and wastage of resources by the ministries, departments and agencies in the State.
\end{abstract}

Keywords: crude oil production quota, debt management, economic development, oil price shocks, public finance, Cross River State

\section{Introduction}

Since the discovery of crude oil in commercial quantities in the country, Nigeria has for so long depended majorly on oil revenue to fund her developmental programmes. The totality of revenue earnings from this source is dependent principally on two factors, namely the quantum of production and the international oil price of the commodity. Being a member of the Organization of Petroleum Exporting Countries (OPEC), both of these factors are determined by forces outside the direct control of Nigeria. Due to forces of demand and supply, oil prices and production quotas are unstable. Over the years, Nigeria has had to deal with the vagaries of the unpredictability of international oil prices and production quotas as frameworks in managing her public finances. The current crash in international oil revenue, which commenced around 2014, is not the first experienced by the country as similar crashes in oil revenues had occurred between 1986 and 2008. Arising from the Arab-Israeli war in 1973, the world witnessed a period of sustained upward swing in crude oil prices until 1980 when there was a glut in the international oil market. The result was that international oil prices started to decline gradually from US\$40 in 1980 to below US\$10 in 1986. A similar scenario occurred two decades later due to the global economic meltdown, which started with the sub-prime mortgage crisis in the United States in 2008. The meltdown resulted in credit crunch, declining asset values and a fall in economic activities and output, a reduction in demand for oil and consequently, oil prices fell from US\$147 in July 2008 to below US $\$ 45$ by December 2008 (Nwankwo, 2015). With the then increasing demand for fossil oil by the global community, the international price of crude oil rose continuously until it reached $\$ 140$ per barrel in 2008 , fluctuated and as late as June 2014, remained above \$100 (Campbell, 2014). Apart from unsteady price movements, the other factor that has impacted negatively on the current total revenue derived from oil is the quantum of production, which is also falling. From its assigned production quota, it is estimated that Nigeria could produce 2.5 million barrels of crude oil per day. However, due to several extenuating conditions, like organized theft, sabotage, ethnic agitations, militancy etc, actual production at the moment seems closer to 1.9 million barrels per day. In addition, the major international oil companies have been cutting back their operations in Nigeria for a variety of economic, political and security concerns (CBN, 2015). The present conundrum could be traced to the last quarter of 2014, when there was a noticeable decline in global demand for oil as a result of the retardation in economic activity 
in China, India and some parts of Europe. Other factors included increased supply of oil with higher exploration levels, including shale oil and gas exploration in the United States and Canada; and, geopolitical manipulations by the western nations in reaction to perceived hostility of Russia in Ukraine. This was in a bid to hurt Russia's economy by depressing its oil export income. As a direct consequence coupled with the decision of OPEC, in November 2014, to retain production levels, the international market for crude oil began experiencing higher supply and lower demand. The combined effect is that oil prices fell from US\$115 in the second quarter of 2014 to below US $\$ 30$ as at January 2016. This unprecedented plunge in prices has left everybody especially OPEC member countries confounded and thoroughly confused. In Nigeria, whose economy is overly dependent on the commodity the situation is dire as despite nominally high growth in the non-petroleum sectors, the country remains a petro-State. More than $90 \%$ of the profits from the petroleum industry go to the Nigerian government, while the product has continued to account for more than $80 \%$ of all government revenue and more than $90 \%$ of the country's exports (CBN, 2015). This over dependency and the current situation in the industry is now stirring serious fiscal concerns throughout the country as most States and local government areas revenues are intrinsically tied to the Federal allocation.

This is so because the Nigerian Federal revenue is based on a conservative estimate of the world price of oil and production quota. This is used in indicating the national budgetary benchmark. The Federal government distributes oil revenue monthly through the federation account allocation committee (FAAC) by a set formula to the Federal government, as well as States and local government authorities. These levels of government are mostly dependent on this monthly revenue because they usually raise little through internally generated revenues defined by local taxes, fines, fees and other in receipts on their own impoverished and under-developed local economies (NPC, 2013). The objective of this study and, therefore, it incremental contribution to knowledge is to interrogate the effect of dwindling oil revenue on the economic growth and development of Cross River State, a sub national. Deriving from the above objective, the research attempts to answer the question, to what extent the plunge in oil revenue affect implementation of programmes as conceptualized in the various budgets of CRS between 2005 and 2014? To proffer a useful answer to the research question, we have formulated the under-listed hypothesis which shall be tested;

Ho: There is no significant relationship between dwindling national oil revenue and the economic growth and development of CRS.

The study covers a 10 (ten) year period between 2005 and 2014, which provided a long enough time frame to reach reasonable conclusions on the subject matter.

\section{Literature Review}

This research paper is built on the theoretical framework of the neo-classical theory of economic development. According to this theory, which has its origin in classical economics, all economic development in the short-run, especially during economic recession or depression is dependent on aggregate demand, which is defined as the total spending in the economy. The Keynesian economists had argued that in any economy the total amount of spending has a direct effect on the total output of goods and services produced and also on inflation. Its conclusion is therefore that an increase in aggregate demand would invariably lead to a corresponding increase in economic development and vice versa (Samuelson, 1976). To evaluate performance of an economy, we could use macroeconomic measures like the gross domestic product (GDP) or the gross national product (GNP). The GDP is the total monetary value of finished goods and services produced in a country within a calendar year. In effect, this represents the size of the economy. The GNP on the other hand is the total value of goods produced and services provided by a country during a year. It represents the economic performance of what the citizens produced within its borders. It is usually equal to the GDP plus the net income from foreign investments (Samuelson, 1976). At the State level, the gross State product (GSP) is the value of such goods and services produced in the State within the same time line. The GSP would be used for this work since it involves a State in Nigeria

\subsection{The Oil Sector and the Nigerian Economy}

In Nigeria, though there is humongous dependence of the sub-national units on Federal generated revenue, however there are no known studies on the impact of such revenues on the States or sub-national entities. Occasionally, the international crude oil market passes through some shocks which are defined by Hamilton (2000) as unpredictable changes, especially downward changes in the international prices of crude oil. These changes or fluctuations are inadvertently expected to have major impact not only on the economies of the oil producing countries but also on the global economy as a whole. According to Hamilton (2000), oil shocks have caused several economic recessions, which is defined as two or more consecutive quarters of negative growth in an economy. Lee, et al (1995) were amongst the earliest to investigate the impact of oil price changes on the economy, using the generalized autoregressive conditional 
heteroscedasticity (GARCH) model. Through this model, they found that oil price volatility was generally highly significant in explaining economic growth in an economy. Elder \& Serletis (2008) studied the impact of uncertainty in oil prices on economic activities in the US, concentrating on the modern OPEC period using the conditional standard deviation of the forecast error for variation in the international price of oil. They found a very significant but negative effect of uncertainty in oil price and real economic activity for the period after 1975. They also found that uncertainty in price also tends to reinforce a decline in real GDP in response to higher prices, while moderating the immediate response of real GDP to lower prices. According to industry watchers, an oil-price decrease in the international market, invariably leads to a transfer of income from exporting to importing countries through a shift in the terms of trade. The extent of the direct effect of a given price decrease would depend on the proportion of the cost of oil in the gross domestic product, the level of dependence on exported oil and the ability of end-users to find close substitutes. In net oil-importing countries, higher oil prices promote inflation, increased input costs, reduced non-oil demand and lower investment and vice versa. Tax revenues fall and the budget deficit increases, due to rigidities in government expenditure, which would eventually drive interest rates up. Given the resistance to declines in wages, an oil price increase typically leads to upward pressure on nominal wage levels, thereby stimulating wage pressures with attendant implications which manifest, possibly in all the postulated channels: supply, demand, economic policy reaction, valuation and asymmetric response (Akinyele \& Ekpo, 2013). Ever since the importance of revenue from crude oil was recognized, the question of the direct linkage between oil price and economic growth has become very important in the field of macroeconomics. While some studies located a significant relationship between global oil prices and economic activity in the United States in the period before 1972, others found a poor linkage between the two variables after 1973. In a similar manner, some researchers have opined that the seeming weakening of the observed relationship between the variables is an illusion arguing that rather, the actual relationship is unbalanced with the relationship between downward oil price and output being different from increased oil prices and output (Mordi \& Adebiyi 2010). Mork (1989) studied the relationship between fluctuations in global oil prices and the GNP in the United States. He found out that GNP continued to improve when the study period was extended to 1986 at the time there was international collapse in oil prices. Though the negative correlation between the variables continued, the real effects of decrease in oil prices differ from those of increases in the price of the commodity, with the decreases not having a significant impact on the nation's economy. Before the discovery of crude oil in commercial quantity in the country, agriculture was the major source of economic development. The groundnut pyramids, cocoa farms and palm plantations of the Northern, Western and Eastern regions, respectively were the major sources of earnings that drove the development programmes of the country. That the Nigerian economy has become compulsively an oil dependent economy is evident as crude oil sale has for decades accounted for about $80 \%$ of total revenue accruable to the federation account, $95 \%$ of foreign exchange earnings, $15 \%$ of the GDP and $4 \%$ of total employment (Agbaeze, Udeh \& Onwuka, 2015). As a result of the above, any major shock in the international crude oil market negatively affects the Nigerian economy. Despite the above trend, Nigeria's crude oil production has declined consistently since December 2013. This has been compounded by the decline in crude oil price which is now well below the $\$ 38$ per barrel budget benchmark for the 2016 budget. Expectedly, a continuous weak crude oil demand would continue to push the price down and if this scenario crystallizes, implementation of the 2016 budget will be in serious jeopardy with far reaching implications for the budget of the Federal, State and local government in Nigeria. The national budget being the ultimate mechanism of fiscal navigation in Nigeria, any factor that can potentially affect it would be of interest to policy makers and politicians as a whole.

As stated above, the Nigerian national budget has over the years been overly tied to the oil sector, with government revenue and expenditure always fluctuating in line with oil prices and production dynamics. During periods of oil boom, the Nigerian government passionately expanded expenditure and embarked on unguarded new projects in her budgets. When oil prices crashed, the economy suffered intense shock from discontinuity of programmes and projects, resulting in costly and wasteful distortions and dislocations of economic activity. Specifically, Nigeria is currently suffering immensely because apart from the dwindling prices, she is currently losing her major traditional crude oil customers like United States of America and China, while at the same time there are new African markets in Angola, Ghana, Gabon, and Algeria. Several researchers have undertaken studies to evaluate the effect of fluctuating crude oil prices on the Nigerian economy. Experts have argued that with the continuous decline in earned revenue from the national coffers, government's desire to provide tangible and intangible assets and services through the appropriation bill will be greatly impeded (Aremo et al, 2012). Before the current dwindling oil prices, CRS had to contend with a decline in revenue from the federation account as a result of the loss of some oil wells to the neighbouring Akwa Ibom State. As a result of the judgment of the international court which granted ownership of the oil rich Bakassi peninsular to the Cameroun, Cross River State in 2007, lost her status as an oil producing State. One of the direct consequences of this situation was that the State lost most of the revenue that used to accrue to her from the 
federation account as an oil producing State. The above scenario has been further compounded by the fall in international crude oil prices which led to cash crunch both at the national and State levels. The State governments usually respond to this conundrum in different ways. While the immediate recourse was to halt implementation of certain programmes in the budget, others resort to debt or borrowing. These resulted in CRS, as with most other Nigerian States, experiencing fiscal imbalances as a result of the bank loans and other debts raised to make up for revenue short falls from the federation account. To cushion the effects of the drop in international oil prices, experts have called on Nigeria and federating States to improve their earnings by diversifying their revenue bases in the long run. In the case of CRS, despite the low and cascading earnings from the FAAC, the present State government is pursuing an expansionary fiscal policy to boost the economy through heavy injection of off-shore funds into key infrastructural and economic spending. Thus a total expenditure of N350 billion was proposed in the 2016 budget as against N127 billion for the previous year (CRS Appropriation Bill 2016).

\subsection{How Nigeria Has Managed Dwindling Oil Revenue}

A comparison of the impact of oil revenue crash shows that Nigeria is coping better with the current oil price crash that began in 2014, than it did with earlier occurrences. The reason why the country is now more resilient and coping better is that the country has been on a path of sustained economic reforms and structural transformation. As a consequence of the dwindling oil revenues, governments at all levels in Nigeria are getting more aggressive on taxation and other fiscal activities as well as non-oil revenues. This has been the experience in other countries that have had similar experiences. In this direction, the Federal government has indicated its intention to increase focus on non-oil revenue sources and place a tax on luxury products. There has, therefore, been fiscal responsibility demand for increased scrutiny of the tax compliance of companies and of their owners. Many companies hit by exchange losses may still have huge current tax bills where the exchange losses remain unrealized at reporting date.

In 2004, the Federal government adopted oil price-based fiscal rule under which oil revenues earned above a reference benchmark oil price are saved in an excess crude account (ECA), which was created to provide for the proverbial rainy day. This is simply an exemplification of the volatility and unreliability of oil revenues - recognition that not all of oil revenue received in any current period belongs to that period. Though the adoption of this strategy has helped to smoothen government expenditure and increase public saving for times of low earnings, the programme has come under intense odium by some State governments who read political meanings to its adoption (Yusuf, 2015).

Another strategy is the effort at curtailing leakages, waste and corruption in the fiscal regime of the country through strategic reform programmes. Compared to its state during the oil-price crash of three decades ago, the Nigerian economy seems better prepared to weather the storm because of the sustained reforms and initiatives. These reforms have taken place both in macroeconomic policy management and in structural transformations in the real sector. The government integrated financial management and information system (GIFMIS), was introduced for the efficient and accountable use of public resources and to guide the allocation of resources to address national priorities. A component of GIFMIS is efficient cash management through the use of the treasury single account (TSA) to centralize government's revenue collection and payments to optimize cash management efficiency and ultimately align borrowing with actual cash flows. Another component of the reforms is the integrated payroll and personnel information system (IPPIS), which intends to enhance payroll management and weed out "ghost workers," thereby reducing leakages in the system (Nwankwo, 2015).

Evidence of continuously improving public finance management and the commitment of Federal government to fiscal consolidation, is obvious in the drastic reduction of the fiscal deficit-to-GDP ratio over the years. Whereas in 1986, the deficit-GDP ratio was $11.94 \%$, in 2014 it was only $1.2 \%$ and as per the 2015 expenditure framework, it was put at $0.79 \%$. In addition, the government initiated moves to boost non-oil tax revenue through various sources. This measure has proved effective in raising non-oil tax revenue. According to Nwankwo (2015), with the establishment of the debt management office (DMO) in 2000, there has been a change in the approach to public debt management, with anticipation of stress situations - a perspective, which was lacking during previous periods of oil price crash. This revived the domestic bond market and provided a leeway for the public and private sectors to raise long-term funds. This facility enables the government to conduct counter-cyclical expenditure interventions in times of economic crisis, in a non-inflationary manner, as evidenced during the $2008-2010$ global economic and financial crises. The DMO conducts a debt sustainability analysis annually and has developed a medium term debt management strategy. These initiatives have, through anticipating possible shocks to the economy, helped to formulate appropriate responses in the event of such occurrences. For example, it is in anticipation of oil price crashes that the DMO has ensured that Nigeria operates on a borrowing ceiling which is about $60 \%$ below the country's peer group threshold. This precaution was evidently non-existent in the past.In addition, since 2008, the DMO has worked with State governments to develop sound debt management practices at the sub-national level with the establishment of similar departments in the 36 
States and the FCT. As a result, States now have accurate data on their debt portfolio. Although this institution-building initiative is still work-in-progress, there is no doubt that Nigeria and the federating States are much stronger in public debt management this time than in the past. To further give State governments some respite, the DMO proposed restructuring of the short-term bank loans into long-term Federal government-backed bonds. The objective was to reduce the debt-service ratio outflows of States and free monetary resources to meet other germane services like payment of civil servant salaries, pensions etc.

As at 2014, the DMO revealed that twenty three States had submitted formal presentations for the restructuring of these debts and the requests were treated in phases with the first phase consisting eleven States. These States' bank loans were restructured into twenty year FGN bonds with effect from 2015, while the second phase had twelve States whose loans were also restructured into 20 year FGN bonds with effect from September of the same year. In the first phase, fourteen banks were involved in the operations with a total amount being $\mathrm{N} 322.788 \mathrm{~b}$, while the second phase had twelve banks with the sum of N252.728b, bringing the total for the twenty three States to N575.516b. The effect of the restructuring was that monthly debt service burden for the States dropped by a minimum of $55 \%$ and a maximum of $97 \%$ among the 23 States involved. Also, the exercise was beneficial to the banking sector because the balance sheets of the banks involved showed great improvements as poor quality sub-national loan assets were replaced with high quality sovereign assets (Nwankwo, 2015).

\section{Research Methodology}

\subsection{Research Design}

For this study, the ex-post factor research design was adopted due to the fact that the events being analyzed had all occurred, with the researchers being in no position to influence the variables. To examine the relationship between the variables, this paper relied predominantly on secondary data that was pooled and accumulated over time. Specifically, the paper used the Bonny light crude oil price and production statistics since this accounts for more than 55 per cent of the Nigerian crude oil export. Also, data on budget implementation was obtained at the State level to ascertain how fluctuations in revenue from oil have affected the implementation of the State budget.

\subsection{Sources of Data}

These data are time series and cross-sectional in nature. The data are of regular nature, maintained and monitored by the relevant financial regulatory agencies of the FGN and the CRS, such as the CBN, the CRS Department of Budget, the State Accountant General's Office and the State Planning Commission.

\subsection{Techniques of Data Collection and Analysis}

In gathering the data, the desk survey method of data collection was employed having in mind the study objective and hypothesis. Trend data were gotten for the period between 2006 and 2014. The data were the gross State product (GSP), average crude oil price (ACOP) and average crude oil production quota (ACOPQ) for the country, the State's allocation from the federation accounts (FAAC), total internally generated revenue (TIGR) as well as total expenditure (TEXP) with a view to establishing the effect of dwindling international oil prices on the economic growth and development of the State. We are satisfied that the data are reasonably accurate and reliable bearing in mind the in-built checks and balances within the originating sources. Both descriptive and inferential statistics were employed to summarize, present and describe the data for better understanding of the subject matter being investigated.

Furthermore, the technique of data analysis adopted in the study was the ordinary least square of multiple regressions. This technique was chosen due to its best linear unbiased estimate feature with in-built validation criteria used in establishing relationships among variables.

\subsection{Model Specification}

The model which was deployed in analyzing the phenomenon took a lead from the models of similar prior studies. The specification is based on the neo-classical theory of development highlighted earlier. Therefore, the model specification is the eclectic approach, expressed as (Equation 1);

$$
\mathrm{GSP}=\mathrm{f}\{\text { ACOP, ACOPQ, FAAC, TIGR, TEXP }\}
$$

Where;

$$
\begin{aligned}
& \mathrm{GSP}=\text { Gross State Product } \\
& \mathrm{ACOP}=\text { Average crude oil price } \\
& \mathrm{ACOPQ}=\text { Average crude oil production quota for the country }
\end{aligned}
$$


FAAC $=$ Receipts from federation account (CRS)

TIGR $=$ Total internally generated revenue $(\mathrm{CRS})$

TEXP $=$ Total expenditure (actual budget performance)

We assumed an approximately linear correlation between the dependent variable and independent variables. Structurally, the above expression is thus stated as follows;

$$
\mathrm{Y}=\beta_{0}+\beta_{1} \mathrm{X}_{1}+\beta_{2} \mathrm{X}_{2}+\beta_{3} \mathrm{X}_{3}+\beta_{4} \mathrm{X}_{4}+\beta_{5} \mathrm{X}_{5}+\mu
$$

Where;

$$
\begin{aligned}
& Y=\text { Dependent variable (GSP of Cross River State) } \\
& \beta_{0}=\text { Regression constant } \\
& \beta_{1}, \beta_{2}, \beta_{3}, \beta_{4}, \beta_{5}=\text { Unknown parameters } \\
& X_{1}, X_{2}, X_{3}, X_{4}, X_{5}=\text { Independent variables (ACOP, ACOPQ, FAAC, TIGR, TEXP). } \\
& \mu=\text { Random term. }
\end{aligned}
$$

Finally, we wish to confirm that the study was not free from limitations as they were bureaucratic bottlenecks encountered in the course of sourcing for data from relevant authorities. The scope was limited to a period between 2006 and 2014, because we could not get data for 2015. However, oil price fluctuations started in 2014.

\section{Data Presentation, Analysis and Discussion of Findings}

\subsection{Data Presentation}

The data on the effect of oil price shock on the economic growth and development of CRS, Nigeria (2005-2014) is presented in Appendix 1.

\subsection{Data Analysis}

Statistical/econometric techniques were used for analysis of the simple regression function and the hypothesis was analyzed independently, using the above techniques. Multiple regression analysis was used in testing whether the set of independent variables explained the dependent variable. Qualitative tools such as interviews of relevant public officials as well as content analysis of official and public documentary sources were also employed.

Table 1. The regression result for oil price shock and economic development in CRS

Dependent Variable: LGSP

Method: Least Squares

Date: 04/05/16 Time: 16:48

Sample: 20052014

Included observations: 9

\begin{tabular}{lllll}
\hline \hline Variable & Coefficient & Std. Error & t-Statistic & Prob. \\
\hline \hline C & -7.061708 & 22.13821 & -0.318983 & 0.7707 \\
LACOP & -0.503672 & 1.869814 & -0.269370 & 0.8051 \\
LACPQ & 1.366843 & 2.915343 & 0.468845 & 0.6711 \\
LFAAC & -0.332166 & 1.078668 & -0.307941 & 0.7783 \\
LTLGR & 1.400426 & 0.645010 & 2.171169 & 0.1183 \\
LTEXP & -0.077026 & 0.918748 & -0.083838 & 0.9385 \\
\hline \hline R-squared & 0.960555 & Mean dependent var & 13.62754 \\
Adjusted R-squared & 0.894814 & S.D. dependent var & 0.756780 \\
S.E. of regression & 0.245441 & Akaike info criterion & 0.263203 \\
Sum squared resid. & 0.180724 & Schwarz criterion & 0.394686 \\
Log likelihood & 4.815587 & Hannan-Quinn criter. & -0.020537 \\
F-statistic & 14.61121 & Durbin-Watson stat & 2.213827 \\
Prob (F-statistic) & 0.025661 & & & \\
\hline \hline
\end{tabular}

Source: Computed from Appendix 1, using E-views 9, 2016. 


\subsection{Discussion of Findings}

Viewing the result in Table 1, it is clear that all variables exert small influences on the GSP of CRS. ACOP, FAAC and TEXP have small inverse impact on the GSP of CRS. In other words, one percent increases in average crude oil price, Federal allocation to CRS and total expenditure of CRS led to marginal decrease in the gross State product of CRS by $\$ 0.50$, N0.33 million and N0.07 million respectively. Again, average crude oil production quota and total internally generated revenue of CRS have small positive impacts on the growth of CRS economy. This is evidently true as one percent increases in average crude oil production quota and total internally generated revenue of CRS led to 1.36 and 1.40 increases in CRS gross State product respectively. The goodness of fit of the model as indicated by the $\mathrm{R}^{2}$ and $\mathrm{R}^{2}$-adjusted values of 0.960555 and 0.894814 respectively showed that the model fits the data well. Particularly, the $\mathrm{R}^{2}$-adjusted value of 0.894814 showed that about 89.48 percent of the total variations in the GSP of CRS have been jointly explained by the independent variables. The overall significance of the model was also tested using the ANOVA or F-statistics. Hence, the high significance of the F-statistics value of 14.61 did not occurs by chance, it actually confirmed that the model fitted the data well. All the variables were not statistically significant using their respective t-statistics values at 5 percent levels. From the results, the DW statistic (2.2138) shows that the model adopted is free from serial correlation of residuals. This implies that the model is econometrically consistent for prediction and forecasting.

\subsection{Test of Hypotheses}

In order to test the already Stated hypothesis, the following decision rule is specified:

Decision rule: Reject the null hypothesis if the f-calculated is greater than the f-tabulated and accept the null hypothesis if the f-calculated is less than $\mathrm{f}$-tabulated.

$$
\text { Result: F-calculated - } 14.611 ; \quad \text { f-critical - } 6.26
$$

Based on these results and decision rule, the null hypothesis was rejected while the alternate was upheld. It was therefore concluded that there is a significant relationship between dwindling national oil revenue and the economic growth and development of CRS.

\subsection{Discussion of Findings}

Findings from this study revealed that there is a small inverse relationship between average crude oil price, Federal revenue allocation to CRS, total expenditure of CRS and the growth and development of the CRS economy for the period under review. This finding reinforces the conclusions of Hamilton (2000) and Lee, et al (1995), that oil shocks tend to cause distortions in economic activities, especially the GDP and other economic parameters. The finding is also in consonance with the findings of Elder \& Serletis (2008) who found a significant but inverse effect of oil price uncertainty and real economic activity and GDP in the United States in the period after 1975. Specifically, our finding could be attributed to the huge amounts of Federal allocated revenue that are sunk into unproductive projects as expenditure may have accounted for this inverse relationship. Again the oil base of CRS is not sufficient enough to generate revenue to boost State expenditure in viable projects, hence, the insignificant linkages. The result also showed a positive but insignificant relationship between CRS internally generated revenue, average crude production quota and the growth of CRS economy. This implies that the internally generated revenue of CRS is insignificant to support expected economic growth and development in CRS. The result may not be very conclusive because as Mork (1989) observed in his study in the US economy, GNP witnessed a continuous enhancement when the period under study is extended beyond 1986 when international crude oil price collapsed. Though the inverse relationship persisted, the effects of a fall in oil price varied from those of increases in the price, with the decreases not having a significant impact on the nation's economy.

\section{Summary Statement of Main Conclusions and Policy Implications}

\subsection{Summary of Main Conclusions}

This research evaluated the impact of oil price shocks on the growth and development of the CRS economy. The Ordinary Least Square (OLS) was adopted to examine the performance of variables on the CRS gross State product for 10 (ten) years, beginning from 2005 to 2014. It revealed that there is a small inverse relationship between average crude oil price, Federal revenue allocation to CRS and the total expenditure of CRS and the gross State product of CRS. There is also a marginal and positive relationship between average crude oil production quota and the total internally generated revenue of CRS and the gross State product.

In the light of the above findings, we conclude that average crude oil price, Federal revenue allocation, total expenditure, average crude oil production quota and total internally generated revenue are weak measures of 
economic growth in Cross River State. While the average crude oil price, Federal allocation and total expenditure are weak negative measures, average crude oil production quota and total internally generated revenue are weak positive measures of economic growth in Cross River State.

\subsection{Policy Implications}

Based on the above finding, the following recommendations were advanced.

1. CRS government should de-emphasize the reliance on crude oil revenue and seek and optimize earnings from other non-oil sectors of the economy.

2. The CRS economy should be diversified to boost internally generated revenue with less dependence on Federal government allocation.

3. There should be effective machinery for checks and balances put up by the government to stem fiscal abuse and wastage of resources by the ministries, departments and agencies in the State.

\section{References}

Agbaeze, E. K, Udeh, S. N., \& Onwuka, I.O. (2015). Resolving Nigeria's dependency on oil - The derivative model. Journal of African studies and development review, 7(1), 1-14. http://dx.doi.org/10.5897/JASD2014.0303

Akinyele, S. O., \& Ekpo, S. (2013). Oil price shocks and macroeconomic performance in Nigeria. Retrieved April 2, 2016, from www.economiamexicana.cida.edu

Aremo, G. A., Orisadare, M. A., \& Ekperiware, C. M. (2012). Oil price shocks and fiscal policy management: Implications for Nigerian economic planning (1980-2009). International Journal of Development and Sustainability, 1(3), 12-29.

Campbell, J. (2014). Can Nigeria endue falling oil prices? Retrieved March 29, 2016, from www.cfr.org

CBN. (2015). Statistical Bulletin. Abuja: Central Bank of Nigeria

CRS Appropriation Bill. (2016). Calabar, Cross River State House of Assembly.

Elder, J., \& Serletis, A. (2008). Oil price uncertainty? Journal of money, credit and banking. Retrieved April 2, 2016, from www.researchgate.net

Hamilton, J. D. (2000). What is an oil shock? Journal of Econometrics, Elsevier, 113(2), 363-398. Retrieved from http://www.nber.org/papers/w7755.pdf

Lee, K., S. Ni, \& R. A. Ratti. (1995). Oil shocks and the macro economy: The role of price variability. The Energy Journal, 16, 39-56.

Mordi, C. N. O., \& Adebiyi, M. A. (2010). The asymmetric effects of oil price shocks on output and prices in Nigeria using a structural VAR model. CBN Economic and Financial Review, 48(1), 1-25.

Mork, K. (1989). Oil shocks and the macro economy when prices go up and down: An extension of Hamilton's results. Journal of Political Economy, 97, 740-744. http://dx.doi.org/10.1086/261625

NPC. (2013). Diagnostic report. Abuja: National Planning Commission. Retreieved April 4, 2016, from www.npc.gov.ng

Nwankwo, A. (2015). Oil price crash and Nigeria: Why this time is different. Sun Newspaper. Retrieved March 20, 2016, from www.sunnewsonline.com

Samuelson, P. A. (1976). Economics (10 ${ }^{\text {th }}$ ed.). Japan, Mcgraw-Hill.

State Bureau of Statistics. (2015). Cross River State Statistics Digest 1997 - 2014, Calabar.

Yusuf, M. (2015). An analysis of the impact of oil price shocks on the growth of the Nigerian economy; $1970-2011$. African Journal of Business Management, 9(3), 103-115. http://dx.doi.org/10.5897/AJBM2014.7458 
Appendix 1. Oil price shock and economic growth indicators

\begin{tabular}{lllllll}
\hline YEAR & GSP & ACOP(\$) & ACPOQ(m) & FAAC(N'000) & TIGR(N'000) & TEXP(N'000) \\
\hline 2005 & 241535.8 & 60.4 & 2.26 & 24003887363 & 2493064316 & 30647263117 \\
2006 & 296359.1 & 65.1 & 2.44 & 30385002944 & 3141503923 & 38113038712 \\
2007 & 415677.2 & 71.1 & 2.35 & 34779866717 & 3396192309 & 36966599271 \\
2008 & NA & 97 & 2.16 & 45683467031 & 6447975865 & 70918431482 \\
2009 & 1109056 & 61.8 & 2.21 & 24188211865 & 7106292956 & 61158209066 \\
2010 & 1319889 & 79 & 2.45 & 27600523707 & 7686098308 & 54858106551 \\
2011 & 1279231 & 101 & 2.55 & 49574586254 & 9159651948 & 86510242729 \\
2012 & 1406234 & 105 & 2.52 & 45231917870 & 12734560333 & 93184486882 \\
2013 & 1491322 & 104.1 & 2.37 & 44246237433 & 12002166999 & 113776099589 \\
2014 & 1576410 & 96.2 & 2.34 & 41789564562 & 13421564337 & 89493211655
\end{tabular}

Sources: State Bureau of Statistics, Office of Accountant General; and CBN Statistical Bulletin, vol., 25, 2014 